\title{
Cellular responses to deproteinized bovine bone mineral biofunctionalized with bone-conditioned medium
}

\author{
Ludovica Parisi $^{1,2,3,4}$ - Daniel Buser ${ }^{2}$. Vivianne Chappuis ${ }^{2}$ - Maria B. Asparuhova ${ }^{1,2}$ (D)
}

Received: 17 July 2020 / Accepted: 13 August 2020 / Published online: 1 September 2020

(C) The Author(s) 2020

\begin{abstract}
Objectives The aim of the study was to investigate whether the osteoinductive properties of bone-conditioned medium (BCM) harvested from cortical bone chips within a clinically relevant short-term period can enhance the biologic characteristics of deproteinized bovine bone mineral (DBBM) in vitro.

Materials and methods To assess the biofunctionalization of DBBM, the adhesive, proliferative, and differentiation properties of mesenchymal stromal ST2, pre-osteoblastic MC3T3-E1, and primary bone-derived cells grown on BCM-coated DBBM were examined by crystal violet staining of adherent cells, BrdU ELISA, and qRT-PCR, respectively.

Results BCM extracted within 20 min or $24 \mathrm{~h}$ in either Ringer's solution (BCM-RS) or RS mixed with autologous serum (BCM$\mathrm{RS}+\mathrm{S}$ ) increased the adhesive properties of all three cell types seeded on DBBM. The 20-min BCM-RS preparation appeared more potent than the 24-h preparation. BCM-RS made within $20 \mathrm{~min}$ or $24 \mathrm{~h}$ had strong pro-proliferative effects on all cell types grown on DBBM. RS + S alone exhibited a considerable pro-proliferative effect, suggesting an impact of the serum on cellular growth. DBBM coated with BCM-RS or BCM-RS $+\mathrm{S}$, made within 20 min or $24 \mathrm{~h}$ each, caused a significant induction of osteogenic differentiation marker expression with a higher potency of the BCM-RS $+\mathrm{S}$. Finally, a strong additive effect of fresh bone chips combined with BCM-coated DBBM on the osteogenic differentiation of the three cell types was observed.

Conclusions Altogether, the data strongly support the biofunctionalization of DBBM with BCM extracted within a clinically relevant time window of $20 \mathrm{~min}$.

Clinical relevance Pre-activation of non-osteoinductive biomaterials with BCM, prepared from autologous bone chips during a guided bone regeneration (GBR) procedure, bears the potential of an optimal treatment modality for bone defects in daily practice.
\end{abstract}

Keywords Bone augmentation · Autologous bone $\cdot$ Bone substitute $\cdot$ Osteogenesis $\cdot$ Growth factors $\cdot$ Gene expression

The authors Vivianne Chappuis and Maria B. Asparuhova share senior authorship

Electronic supplementary material The online version of this article (https://doi.org/10.1007/s00784-020-03528-6) contains supplementary material, which is available to authorized users.

Maria B. Asparuhova

mariya.asparuhova@zmk.unibe.ch

1 Laboratory of Oral Cell Biology, Dental Research Center, School of Dental Medicine, University of Bern, Freiburgstrasse 3, 3010 Bern, Switzerland

2 Department of Oral Surgery and Stomatology, School of Dental Medicine, University of Bern, Freiburgstrasse 7, 3010 Bern, Switzerland
3 Centro Universitario di Odontoiatria, Dipartimento di Medicina e Chirurgia, University of Parma, Via Gramsci 14, 43126 Parma, Italy

4 Present address: Laboratory of Oral Molecular Biology, Dental Research Center, Department of Orthodontics and Dentofacial Orthopedics, University of Bern, Freiburgstrasse 3, 3010 Bern, Switzerland 


\section{Introduction}

Reconstruction of maxillofacial and oral bone defects might represent a clinical challenge that requires the use of bone substitutes [1]. The indications for using bone grafts range from minor fenestration defects to bridging major continuity defects in the facial skeleton. Despite the advances in the generation of new bone substitute materials, autografts are largely considered as the gold standard in osseous reconstructive surgery [2-4]. Indeed, bone derived from the patient own body is the only bone graft that possesses osteogenic, osteoinductive, and osteoconductive properties, thus providing viable osteogenic precursor cells, growth factors as well as physical scaffolding structure to foster new bone formation, and revascularization of the augmented volume [5]. Furthermore, recent laboratory-based evidence supports a paracrine function of the autogenous bone realized through a spectrum of secretory proteins [6] that possess the potential to target cellular processes in various cell types actively supporting the graft consolidation process in vivo [7-9].

Although autografts are considered superior for their consolidation, harvesting requires technical expertise and, depending on the need for an additional harvesting site, can be associated with increased surgical time, hematoma, postoperative pain, neurovascular injury, increased risk of infection, and esthetic deformity at the graft extraction site [10-12]. In addition, often intraoral sites do not provide sufficient quantities of bone for a grafting medium on large alveolar defects [11]. To overcome the shortcomings of the autograft alone, a guided bone regeneration (GBR) technique utilizing a combination of autologous bone chips with a bone graft substitute, such as deproteinized bovine bone mineral (DBBM), and a bioabsorbable collagen membrane was developed [13-15]. The two (autologous and xenogenic) bone fillers, a combination termed composite graft, are applied either in two layers or mixed. This bone augmentation technique has been successfully applied for a number of indications including early implant placement with simultaneous contour augmentation in the esthetic zone [3, 16-18], horizontal and vertical bone augmentation called sausage technique $[19,20]$, and for sinus floor elevation procedures in the posterior maxilla [21]. In addition, the GBR technique using a 2-layer composite graft has demonstrated good long-lasting stability of the peri-implant hard and soft tissues, and excellent esthetic outcomes [3, 18, 22].

The DBBM applied in the GBR procedure combines good osteoconductivity with a low substitution rate [23, 24]. In addition, the lack of organic matrix makes DBBM fully biocompatible, showing minimal risks for foreign body reactions in patients $[25,26]$. However, the processing limits the biological activity of the DBBM, namely its osteogenic and osteoinductive properties. To address this limitation, the paracrine function of the autograft has been utilized in the GBR by pre-hydration of the DBBM and collagen membranes with bone-conditioned medium (BCM) [27-29]. $\mathrm{BCM}$ is a mixture of patient's own blood and physiological solution enriched with autogenous growth factors [30]. These growth factors are released from autologous bone chips harvested from an intraoral site and stored in the mixture of autologous blood and saline for the time of the surgical site and implant bed preparation.

Recently, our laboratory has revealed part of the biological mechanisms that underlie the successful outcomes from GBR procedures utilizing BCM derived from autologous bone $[6-9,31-33]$. It has been demonstrated that the technique by which the autologous bone chips are harvested may significantly influence the cellular viability and the release of growth factors [34]. BCM extracted from bone scraper or bone mill samples has revealed significantly higher expression of growth factors such as vascular endothelial growth factor (VEGF) and bone morphogenetic protein-2 (BMP-2) compared to samples prepared by piezosurgery or bone drilling $[34,35]$. Moreover, higher amounts of newly formed bone in association with autografts harvested by bone mill compared to grafts harvested by bone scraper or piezosurgery were also demonstrated in a histomorphometric study in vivo using a minipig model [36].

More recently, we have shown that the time frame for the BCM extraction from cortical bone affects the BCM composition and the behavior of osteoprogenitors treated with it [33]. In particular, we have demonstrated a significant and very fast release of transforming growth factor- $\beta 1$ (TGF- $\beta 1$ ) from autogenous bone chips within 10 min versus a delayed BMP-2 release from $40 \mathrm{~min}$ on. BCMs harvested within short terms $(10,20$, or $40 \mathrm{~min})$, corresponding to the typical time of a surgical procedure, significantly enhanced the proliferative capacity and collagen matrix production of $\mathrm{BCM}$-treated osteoprogenitors. BCMs extracted within longer periods (1, 3 , or 6 days) exhibited a great capacity to induce the later stages of osteoblast differentiation and matrix mineralization due to the combined activity of TGF- $\beta 1$ and BMP-2.

As a clinically relevant translation of these investigations, we hypothesized that short-term coating of DBBM with short-term extracted BCM potentiates the beneficial properties of the biomaterial. More specifically, the aim of the present study was to investigate whether the biological activity of the BCM can be transferred onto the DBBM in vitro, leading to induced osteogenic properties of mesenchymal stromal cells, pre-osteoblastic cells, and primary human bone-derived cells. The study further aimed to investigate if a synergy between BCM-coated DBBM and freshly harvested bone chips could be detected, thus providing justification for a clinical approach combining autologous bone, BCM, and DBBM, which would completely utilize the osteoinductive properties of the autograft. 


\section{Materials and methods}

\section{BCM preparation and DBBM coating}

The preparation of BCM was described previously [30]. In brief, cortical bone chips from the buccal side of fresh pig mandibles (Slaughterhouse: Küng Metzgerei, Toffen, Switzerland) were harvested by using a bone scraper (HuFriedy, Rotterdam, the Netherlands) and soaked in extracting solutions for $20 \mathrm{~min}$ or $24 \mathrm{~h}$ (Fig. 1a). Extracting solutions, consisting of either Ringer's solution (RS) or RS mixed with autologous serum $(\mathrm{RS}+\mathrm{S})$ in a 1:1 ratio, were supplemented
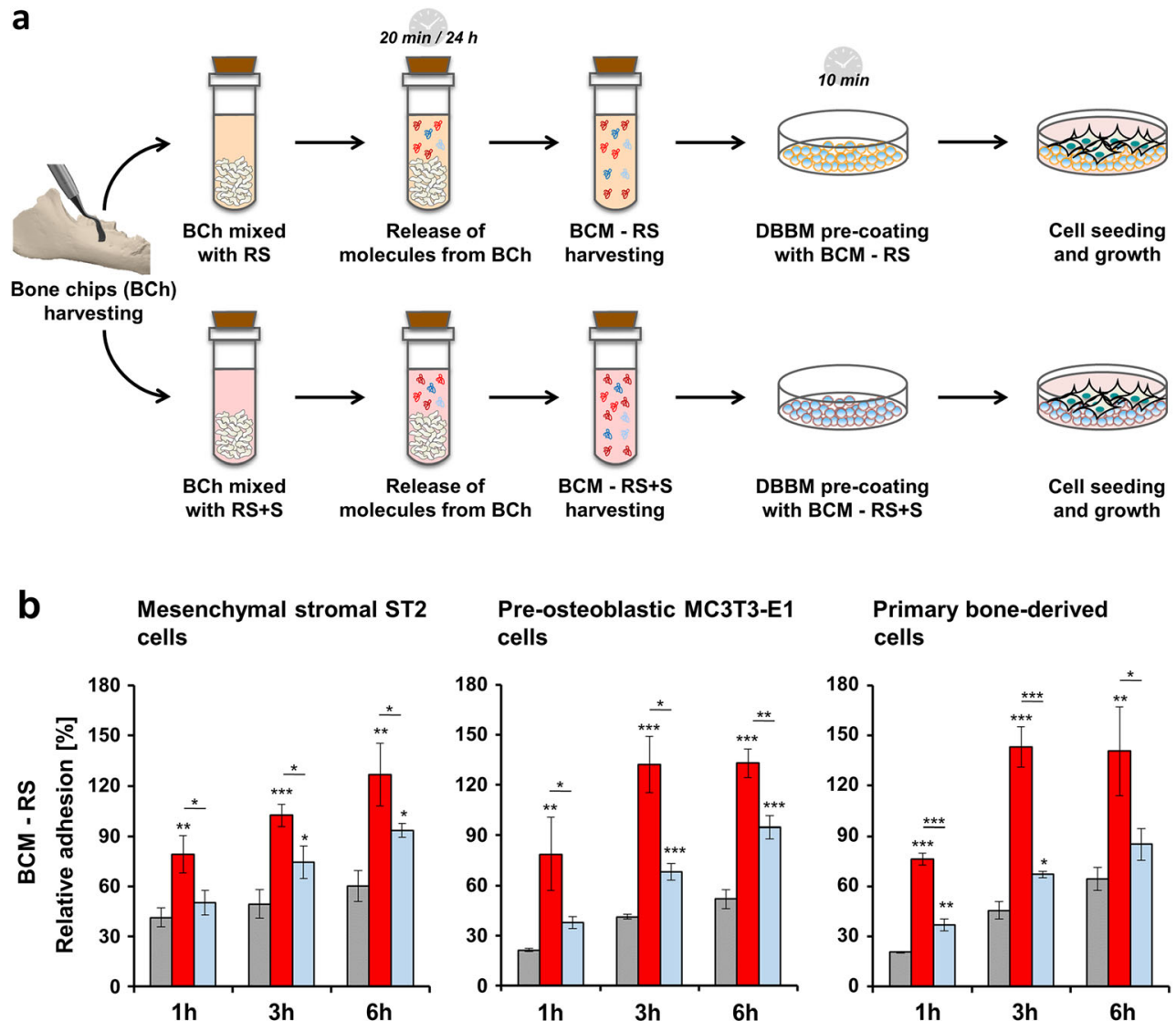

Primary bone-derived
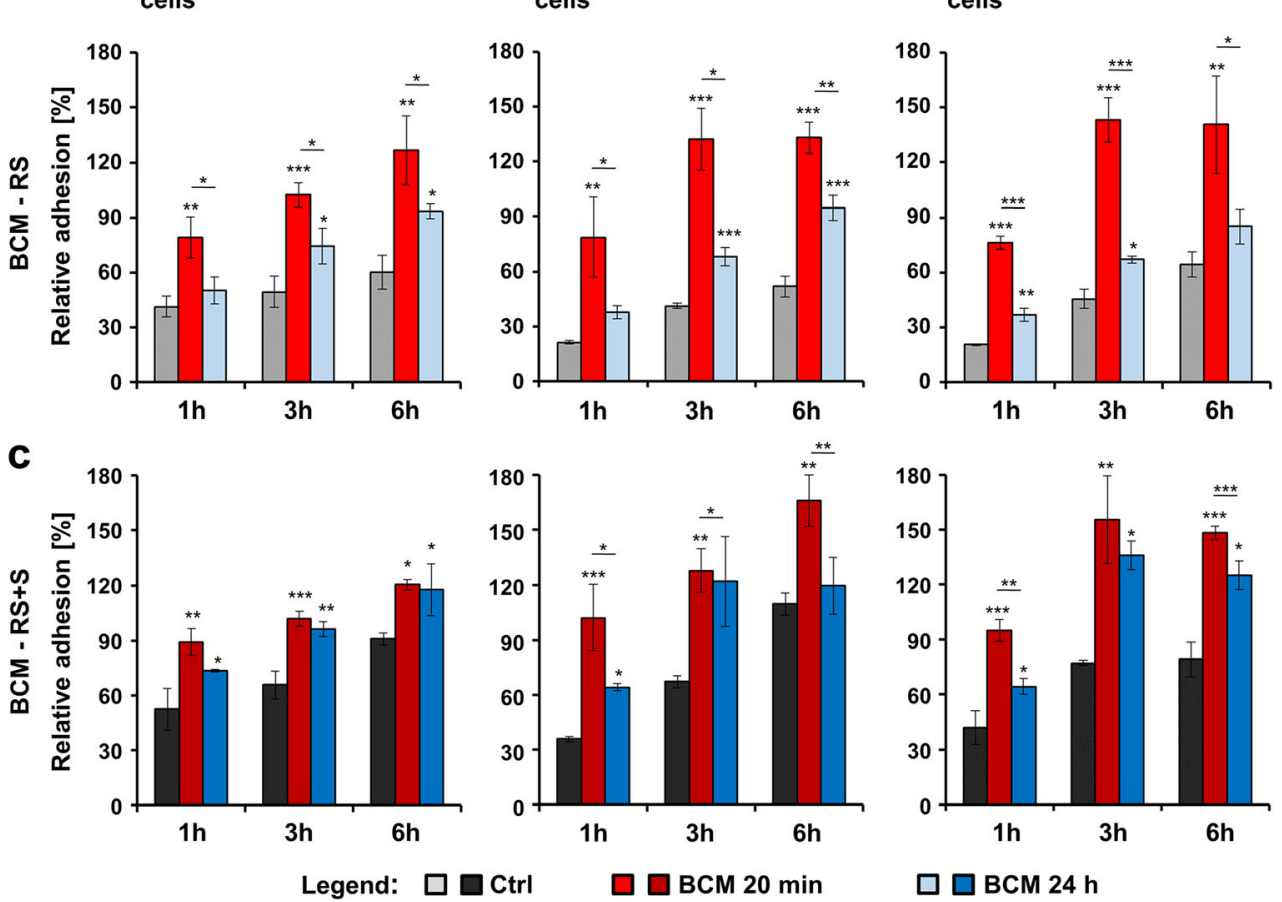

Fig. 1 Increased adhesive properties of bone-related cell cultures grown on BCM-coated DBBM. a Schematic representation of the experimental set-up utilized throughout the study. The following steps are illustrated: (1) harvesting of cortical bone chips $(\mathrm{BCh})$ from the buccal side of fresh pig mandibles using a bone scraper; (2) mixing of the $\mathrm{BCh}$ with extracting solutions consisting of Ringer's solution (RS) or a 1:1 mixture of Ringer's solution and autologous serum (RS $+\mathrm{S})$; (3) incubation of the resulting mixtures for $20 \mathrm{~min}$ or $24 \mathrm{~h}$ during which time release of molecules from the BCh occurs; (4) harvesting of two types of bone-conditioned medium (BCM) labeled as BCM-RS and BCM-RS + S; (5) coating of deproteinized bovine bone mineral (DBBM) with the respective $\mathrm{BCM}$

preparations for $10 \mathrm{~min}$ prior to (6) cell seeding and growth. b, c Adhesion rate of ST2, MC3T3-E1, and primary bone-derived cells plated on DBBM coated with BCM-RS (b) or BCM-RS + S (c) prepared within $20 \mathrm{~min}$ or $24 \mathrm{~h}$ each. Controls (Ctrl) represent cells of each cell type seeded on BCM-free DBBM hydrated with RS or RS $+\mathrm{S}$. Adhesion rates were assessed by crystal violet assay at 1,3 , and $6 \mathrm{~h}$. Experimental values were normalized to the values obtained for the total number of seeded control cells, taken as $100 \%$ adhesion. Means \pm SD from three independent experiments and significant differences to control cells at each time point unless otherwise indicated, $* * * P<0.001, * * P<0.01, * P<0.05$ are shown 
with $1 \%$ antibiotics/antimycotics (AA; ThermoFisher Scientific, Basel, Switzerland). A ratio of $1 \mathrm{~g}$ bone chips per $2 \mathrm{ml}$ medium (50\% weight/volume) was utilized. Two types of media, abbreviated BCM-RS and BCM-RS + S, were collected from three independent preparations. The BCMs were sterile filtered and kept frozen at $-80{ }^{\circ} \mathrm{C}$ until experimental cell seeding.

DBBM (Geistlich Bio-Oss ${ }^{\circledR}$ ) granules in the 0.25-1-mm range size were kindly provided by Geistlich Pharma (Wolhusen, Switzerland). Prior to cell seeding, 35 or $200 \mathrm{mg}$ of DBBM granules (resulting in a layer of a 3-mm height) were placed on the bottom of 96- or 24-well ultra-low attachment plates (Corning, NY, USA), respectively, and coated for 10 min with each of the BCM preparations. Cells seeded on BCM-free DBBM, pre-hydrated with RS or RS $+\mathrm{S}$, were used as controls (Ctrl) throughout the study. Corning $®$ ultralow attachment plates were our product of choice among three different brands tested because it ensured $0 \%$ cell attachment on the plastic surface even after coating with BCM.

A 3D-culturing system was also adopted in the present study. DBBM granules in the 24-well culture system were prepared as described above, and coated with either RS $+\mathrm{S}$ or the 20-min BCM-RS $+\mathrm{S}$ preparation. Immediately after cell seeding, a Nunc ${ }^{\mathrm{TM}}$ polycarbonate cell culture insert (ThermoFisher Scientific) with a $0.4-\mu \mathrm{m}$ pore size was placed in the cell culturing well and filled with $0.5 \mathrm{~g}$ of fresh bone chips as depicted in Fig. $7 \mathrm{a}$.

\section{Cell culture}

Mesenchymal stromal ST2 cells derived from mouse bone marrow were obtained from RIKEN Cell Bank (Tsukuba, Japan). Pre-osteoblastic MC3T3-E1 cells derived from a C57BL/6 mouse calvaria were obtained from ECACC collection (Sigma-Aldrich, Buchs, Switzerland). Both cell lines were grown in Dulbecco's modified Eagle medium (DMEM) supplemented with $10 \%$ fetal calf serum (FCS; Invitrogen, Zug, Switzerland) and 1\% AA (ThermoFisher Scientific). Cells were starved in 0.3\% FCS/DMEM for $24 \mathrm{~h}$ before culturing on DBBM.

Primary human bone-derived cells were obtained from three donors using a modification of previously described techniques [37]. Fresh bone particles harvested from the retromolar area using a bone scraper were retrieved from anonymous and systemically healthy individuals, who had undergone implant placement with GBR procedure at the Department of Oral Surgery and Stomatology, following signed informed consent and approval by the Ethics Committee, Bern, Switzerland. In brief, after extensive washing in excess of sterile PBS for complete removal of blood and dislodged cells, the bone chips were digested using $0.2 \%$ collagenase type II (Worthington Biochemical Corporation, Lakewood, NJ, USA) in Hanks' balanced salt solution for
$30 \mathrm{~min}$, in a humidified atmosphere of $5 \% \mathrm{CO}_{2}$ at $37{ }^{\circ} \mathrm{C}$. Complete culturing medium was used to stop the enzymatic reaction and specimens were placed into a gentleMACS ${ }^{\text {TM }} \mathrm{C}$ Tube (Miltenyi Biotec, Solothurn, Switzerland). GentleMACS Dissociator (Miltenyi Biotec) was used for automated dissociation of the specimens to obtain a single-cell suspension. The suspension was subsequently passed through Falcon ${ }^{\circledR} 70 \mu \mathrm{m}$ Cell Strainer (Corning) before culturing in complete minimum essential medium Eagle-alpha modification ( $\alpha$-MEM; Thermo Fischer Scientific) supplemented with $10 \% \mathrm{FCS}$ and $1 \% \mathrm{AA}$. Cells that had not undergone more than five passages were starved in $0.3 \%$ FCS $/ \alpha$-MEM for $24 \mathrm{~h}$ before culturing on DBBM. Data in each data set were obtained from three independent experiments performed with primary bone-derived cells from three different cell donors. Characterization of the primary human bone-derived cultures, according to published classifications [38,39] and in comparison with the ST2 and MC3T3-E1 strains, revealed them as a mixture of cells with osteoblastic and preosteocytic phenotype (Electronic Supplementary Material, Figure S1). However, no expression of sclerostin, which is considered as a marker of mature osteocytes, was detected in any of the three cell types.

For differentiation experiments followed by RNA analyses, complete media were supplemented with $50 \mu \mathrm{g} / \mathrm{mL}$ ascorbic acid (Invitrogen, Zug, Switzerland) and $2 \mathrm{mM} \beta$ glycerophosphate (Invitrogen) as it was described previously [33].

\section{Cell adhesion assay}

The adhesion capacity of ST2, MC3T3-E1, and primary bone-derived cells cultured on BCM-coated DBBM was determined by crystal violet (Sigma-Aldrich) staining of adherent cells. In brief, $5 \times 10^{4}$ cells/well were plated in duplicate, in complete medium on DBBM in ultra-low attachment 96well plates and allowed to adhere for 1,3 , and $6 \mathrm{~h}$. To test for a potential background staining produced by the BCM-coated DBBM, no cell controls were included in the assay (Electronic Supplementary Material, Figure S2a). After removal of culture medium, cells were extensively washed 3 times in PBS in order to remove any non-adherent cells, then fixed in $4 \%$ paraformaldhyde (PFA; Sigma-Aldrich) for $20 \mathrm{~min}$ at room temperature (RT), and stained with crystal violet solution (0.1\%; Sigma-Aldrich) in PBS for $30 \mathrm{~min}$ at RT. After 8 washing cycles in deionized $\mathrm{H}_{2} \mathrm{O}$ to remove crystal violet excess, the dye bound to adherent cells was solubilized using a 10\% (volume/volume) acetic acid (Sigma-Aldrich) on an orbital shaker at $150 \mathrm{rpm}$ for $5 \mathrm{~min}$ at RT. The absorbance of the eluate was measured at $570 \mathrm{~nm}$ using an EL808 reader (BioTek Instruments GmbH, Lucerne, Switzerland). To obtain a value for the total number of seeded cells as well as to correct for the background signal produced by the BCM, cells of each experimental group were processed in parallel in the 
following way: After removal of the culture medium, cells were directly fixed in 4\% PFA omitting the 3 cycles of extensive wash in PBS. The rest of the procedure was performed as described above. Please, refer to the Electronic Supplementary Material, Figure S2b for more details on the quantitative assessment of the background staining produced by the BCM. Experimental values corrected for the background signal were normalized to the values obtained for the total number of seeded control cells, which were allowed to settle down for $1 \mathrm{~h}$ and processed as described above (conditionally taken as $100 \%$ adhesion). Data represent means \pm SD from three independent experiments performed with each of the three cell types, in duplicates.

\section{Cell proliferation assay}

Proliferation rates of cultured on BCM-coated DBBM ST2, MC3T3-E1, and primary bone-derived cells were determined using a 5-bromo-20-deoxyuridine (BrdU) incorporation ELISA (Roche, Basel, Switzerland) as described [40]. In brief, after starvation of $24 \mathrm{~h}$, cells were plated in triplicate at $1 \times 10^{3}$ cells/well, in 3\% FCS-containing medium on DBBM in black ultra-low attachment 96-well plates and allowed to proliferate for $0,24,48,72$, and $96 \mathrm{~h}$ before a 2-h labeling with BrdU. Incorporation of BrdU into newly synthesized DNA was determined according to the manufacturer's protocol using an Infinite ${ }^{\circledR} 200$ luminometer (Tecan, Männedorf, Switzerland). Experimental values were normalized to the values of control cells at the time point 0 . Data represent means \pm SD from three independent experiments performed with each of the three cell types, in triplicates.

\section{RNA analysis by quantitative reverse transcription- polymerase chain reaction}

For RNA analyses, cells were plated at $2.5 \times 10^{5}$ cells/well, in differentiation medium on DBBM in ultra-low attachment 24well plates. Total RNA from cells grown on BCM-coated DBBM in the absence or in the presence of fresh bone chips (Fig. 7a) for 1, 3, and 7 days was isolated using Trizol (Thermo Fisher Scientific) according to the manufacturer's protocol. The extracted RNA was additionally purified by using the RNeasy MinElute Cleanup Kit (Qiagen, Basel, Switzerland). RNA, quantified on a NanoDrop 2000c instrument (ThermoFisher Scientific), was reverse transcribed and relative transcripts for collagen type I (Colla1), runt-related transcription factor 2 (Runx2), alkaline phosphatase (Alpl), and osteocalcin (or bone gamma-carboxyglutamate protein 2, Bglap2) genes, normalized to Gapdh, were measured using FastStart Universal SYBR Green Master ROX (Roche), and the primer sequences listed in Electronic Supplementary Material, Tables S1 and S2. The two tables include four additional osteogenic marker genes that were used in the characterization of the primary human bone-derived cells (for more details, please refer to the Electronic Supplementary Material, Figure S1). For simplicity, the same non-capitalized symbols were used for both mouse and human genes throughout the paper except in Table S2, where human gene symbols were capitalized. qPCR was carried out in a QuantStudio 3 instrument (Applied Biosystems, Rotkreuz, Switzerland) using a standard thermal cycling profile. The efficiency $\Delta \Delta \mathrm{Ct}$ method [41] was used to calculate gene expression levels normalized to Gapdh values and calibrated to values of controls at day 1 . All samples were run in duplicates. Data represent means \pm SD from three independent experiments performed with each of the three cell types.

\section{Statistical analysis}

All grouped data are means \pm SD. Statistical analysis was performed using GraphPad InStat Software (GraphPad, La Jolla, CA, USA), version 3.05. Multiple comparisons were completed using one-way analysis of variance (ANOVA) with Tukey's post hoc test. Values of $P<0.05$ were considered significant.

\section{Results}

\section{Increased adhesive properties of bone-related cell cultures grown on BCM-coated DBBM}

Figure 1a depicts the experimental set-up used throughout the study. Bone chips harvested from the buccal side of fresh pig mandibles were mixed with either RS or RS + $\mathrm{S}$. The resulting BCMs, BCM-RS and BCM-RS $+\mathrm{S}$, extracted for either $20 \mathrm{~min}$ or $24 \mathrm{~h}$ each, were used for a short 10 min-coating of DBBM prior to cell seeding and growth for different time intervals.

We first investigated the adhesive properties of the mesenchymal stromal ST2, pre-osteoblastic MC3T3-E1, or primary human bone-derived cells seeded either on control BCM-free DBBM hydrated with RS or RS + S, DBBM coated with the 20-min BCM preparation, or DBBM coated with the 24-h $\mathrm{BCM}$ preparation. The $\mathrm{BCMs}$ were made in each of the two diluents, RS (Fig. 1b) or RS + S (Fig. 1c). Adhesion was followed over 1,3 , and $6 \mathrm{~h}$ using crystal violet assay. The results showed that in comparison to controls, BCM extracted within $20 \mathrm{~min}$ in RS significantly $(P<0.01)$ increased the adhesive properties of all three cell types seeded on DBBM (Fig. 1b). With few exceptions, the 24-h BCM-RS preparation also caused significant $(P<0.05)$ increase in the adhesive potential of the three cell types seeded on DBBM. Interestingly, in all three cell types, the 20-min BCM preparation appeared to be more potent than the 24-h preparation (compare red with blue bars, $P<0.05$ ). 
A similar behavior was detected for cells seeded on DBBM coated with BCM-RS $+\mathrm{S}$ prepared for either 20 min or $24 \mathrm{~h}$ (Fig. 1c). However, the 20-min BCM preparation appeared to be significantly more potent than the 24 -h preparation in the case of MC3T3-E1 pre-osteoblasts $(P<0.05)$ at each time point and in the case of the primary bone-derived cells $(P<0.01)$ at 1 and $6 \mathrm{~h}$. Interestingly, control cells seeded on BCM-free DBBM pre-coated with RS + S (dark gray bars, Fig. 1c) were characterized with higher but not significant relative adhesion values compared to control cells seeded on DBBM pre-hydrated with RS (light gray bars, Fig. 1b). This suggests that to a certain extent, serum proteins along with BCM contribute to the increased adhesive properties of the investigated cell types.

\section{Pro-proliferative properties of bone-related cell cul- tures grown on DBBM coated with BCM-RS}

We further evaluated the proliferative rate of ST2, MC3T3E1, and primary bone-derived cells grown on BCM-coated DBBM (Fig. 2). Compared to control cells grown on DBBM hydrated with RS, cells grown on DBBM coated with BCMRS preparations made within 20 min or $24 \mathrm{~h}$ showed a strong increase in BrdU uptake into newly synthesized DNA until a confluence was reached (Fig. 2a). Compared to the respective controls, the detected increase was in the range of 3.9-4.5-fold for ST2 and MC3T3-E1 cell lines and 6.0-7.5-fold for the primary bone-derived cultures grown on the BCM-coated DBBM. Most importantly, the short-term 20-min BCM preparation was as potent as the 24-h preparation except for ST2 cells after $24 \mathrm{~h}$ of growth, at which time point the $24-\mathrm{h}$ BCM preparation exhibited a significantly higher $(P<0.05)$ proliferative rate than the 20-min preparation.

In contrast to the effects caused by the BCM-RS-coated DBBM, no significant differences in the proliferative rates of control cells grown on DBBM hydrated with $\mathrm{RS}+\mathrm{S}$ and cells grown on DBBM coated with BCM-RS $+\mathrm{S}$ preparations made within $20 \mathrm{~min}$ or $24 \mathrm{~h}$ were detected for any of the three cell types over 5 days (Fig. 2b). Notably, for each of the three cell types, the growth rates of control cells seeded on RS + Scoated DBBM were considerably higher (in the range of 3.16.9-fold) compared to control cells seeded on RS-hydrated DBBM (Fig. 2a and b). This finding suggests a significant impact of the serum on the proliferative ability of the three cell types, which may be further extrapolated to the patient's own blood used to store the autologous bone chips during the surgical tooth bed preparation.

\section{BCM-coated DBBM induces osteogenic differentiation of bone-related cell cultures}

As a next step, we investigated the expression of osteogenic differentiation markers such as Colla1 (Fig. 3), Runx2 (Fig. 4), Alpl (Fig. 5), and Bglap2 (Fig. 6) in cells grown on BCM-coated DBBM for 1, 3, and 7 days. DBBM coated with BCM made within $20 \mathrm{~min}$ or $24 \mathrm{~h}$, in each of the two solutions (RS or RS $+\mathrm{S}$ ), caused a significant increase in Colla1 (Fig. 3) and Runx2 (Fig. 4) mRNAs above the levels
Fig. 2 Proliferative properties of bone-related cell cultures grown on BCM-coated DBBM. a, b Proliferative ability of ST2, MC3T3-E1, and primary bonederived cells grown on DBBM coated with BCM-RS (a) or $\mathrm{BCM}-\mathrm{RS}+\mathrm{S}(\mathrm{b})$, was assessed by BrdU incorporation into newly synthesized DNA immediately after plating $(0 \mathrm{~h})$ as well as at 24 , 48,72 , and $96 \mathrm{~h}$. Cells of each cell type grown on BCM-free DBBM that is hydrated with RS (a) or RS $+\mathrm{S}(\mathrm{b})$ are used as controls (Ctrl). Experimental values were normalized to the values of control cells at the time point 0 . Means \pm SD from three independent experiments and significant differences to control cells unless otherwise indicated, $* * * P<0.001$, $* * P<0.01, * P<0.05$ are shown
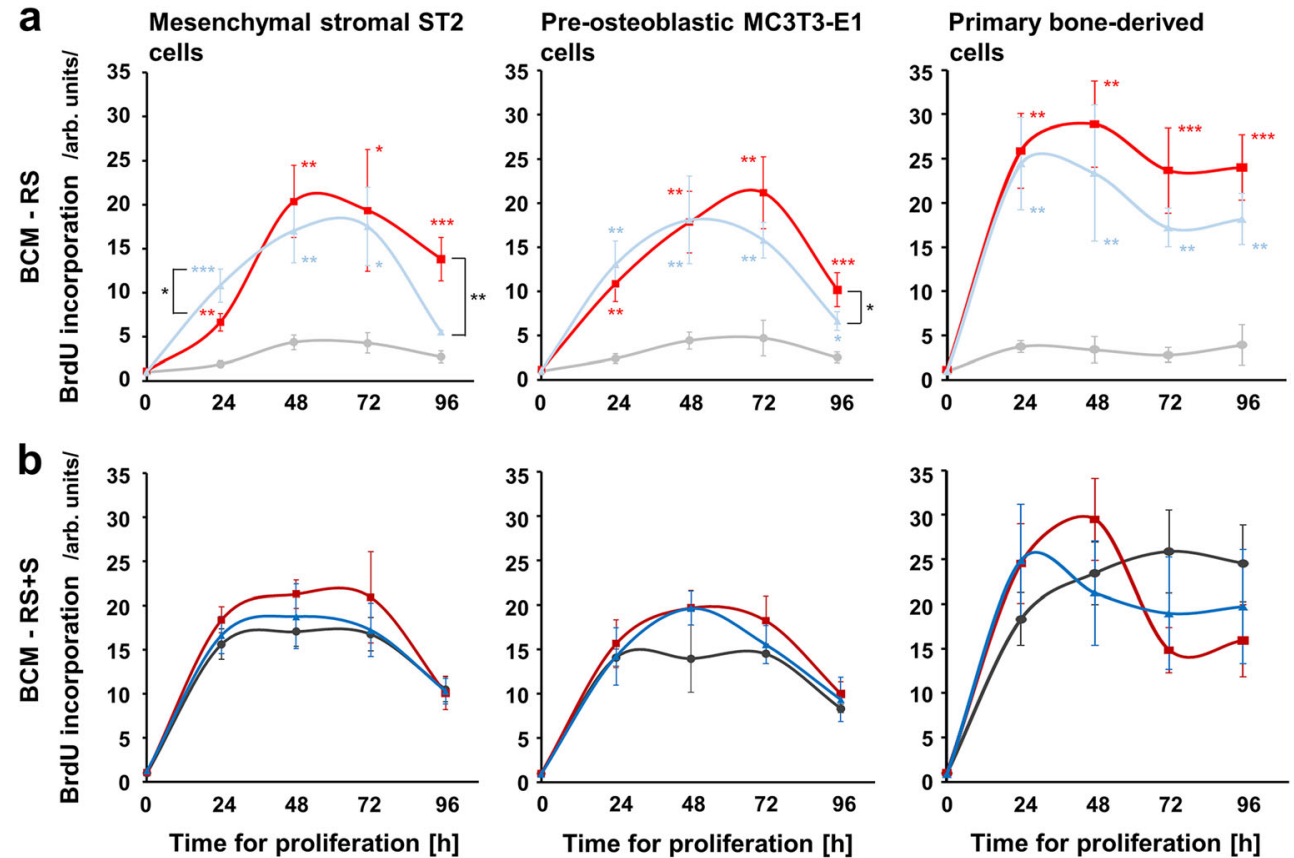

Legend:

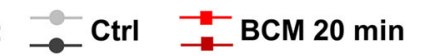

BCM $24 \mathrm{~h}$ 
Fig. 3 BCM-coated DBBM induces Collal gene expression in bone-related cell cultures. a, $\mathbf{b}$ ST2, MC3T3-E1, and primary bone-derived cells were grown on DBBM coated with BCM-RS (a) or BCM-RS + S (b) for 1, 3, and 7 days before total RNA was isolated and analyzed for Colla1 expression by qRT-PCR.

Controls (Ctrl) represent cells of each cell type seeded on BCMfree DBBM hydrated with RS (a) or $\mathrm{RS}+\mathrm{S}(\mathrm{b})$. Values normalized to Gapdh are expressed relative to the values of control cells at the "1 day" time point. Please note the differences in the scales of the $y$-axis. Data represent means \pm SD from three independent experiments. Significant differences to the respective controls at day 1 unless otherwise indicated,

$* * * P<0.001, * * P<0.01$,

$* P<0.05$ a

Mesenchymal stromal ST2 cells

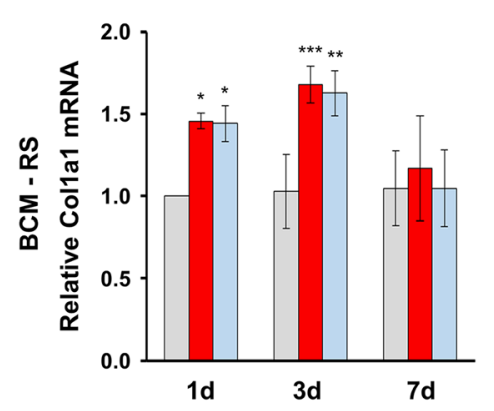

b

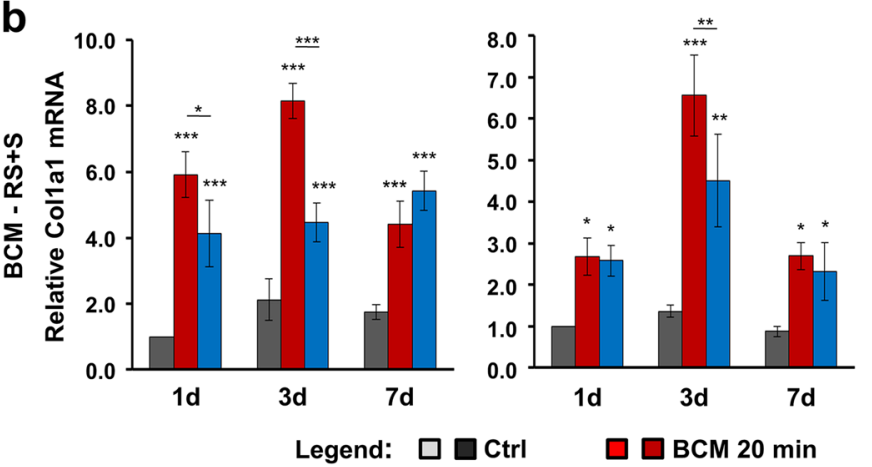

Primary bone-derived cells
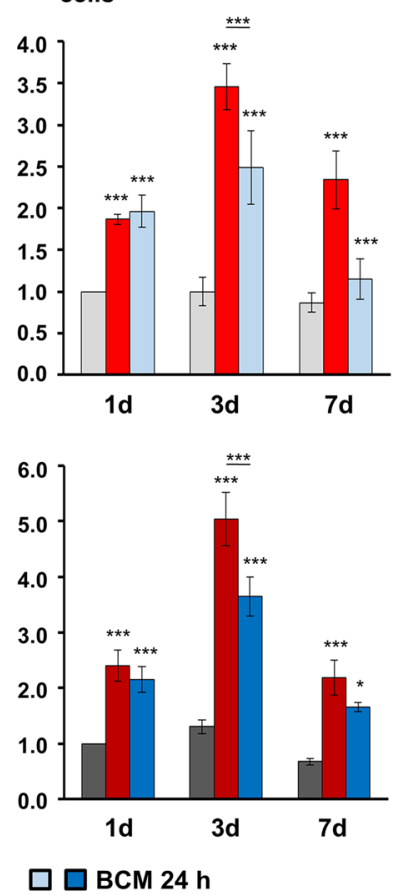

expressed and detected in control cells grown on DBBM prehydrated with the diluents alone. The qRT-PCR analyses showed two clear trends. First, a tendency of a higher potency exhibited by the 20 min compared to the $24-\mathrm{h} \mathrm{BCM}$ preparation, especially in MC3T3-E1 and primary bone-derived cells (Figs. 3 and 4) as well as for individual time points in the ST2 cells grown on BCM-RS + S-coated DBBM (Fig. 3b and 4b), was observed. Second, a consistent fashion of a higher potency exhibited by the DBBM coated with BCM-RS $+\mathrm{S}$ in all three cell types was observed (refer to the difference in the scales between $a$ and $b$ in Figs. 3 and 4). Following a significant increase at days 1 and 3, Collal expression at day 7
Fig. 4 BCM-coated DBBM induces Runx 2 gene expression in bone-related cell cultures. $\mathbf{a}, \mathbf{b}$ ST2, MC3T3-E1, and primary bone-derived cells were grown on DBBM coated with BCM-RS (a) or BCM-RS $+\mathrm{S}$ (b) for 1, 3, and 7 days before total RNA was isolated and analyzed for the expression of the transcription factor gene Runx 2 by qRT-PCR.

Controls (Ctrl) represent cells of each cell type seeded on BCMfree DBBM hydrated with RS (a) or RS + S (b). Values normalized to Gapdh are expressed relative to the values of control cells at the "1 day" time point. Please note the differences in the scales of the $y$-axis. Data represent means \pm SD from three independent experiments. Significant differences to the respective controls at day 1 unless otherwise indicated, $* * * P<0.001, * * P<0.01$, $* P<0.05$ a

Mesenchymal stromal ST2 cells

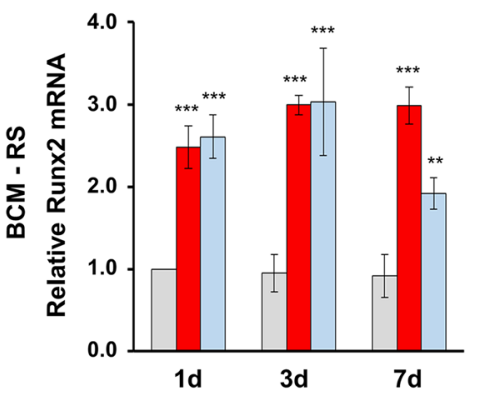

b

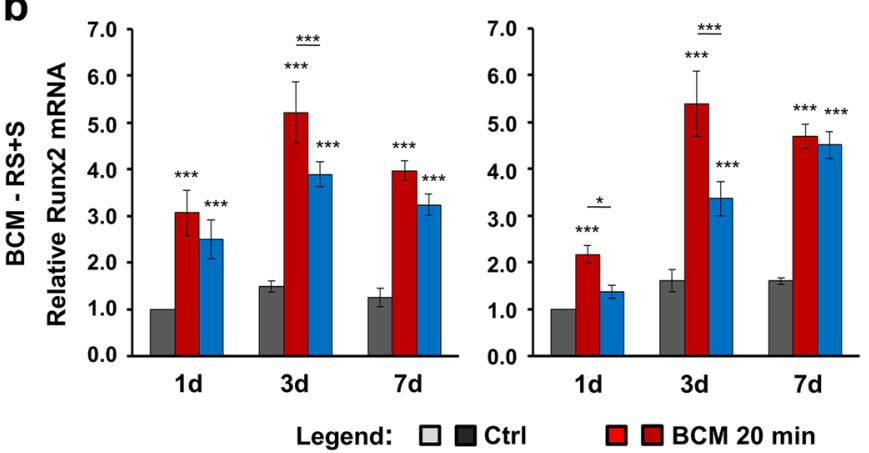

Primary bone-derived cells
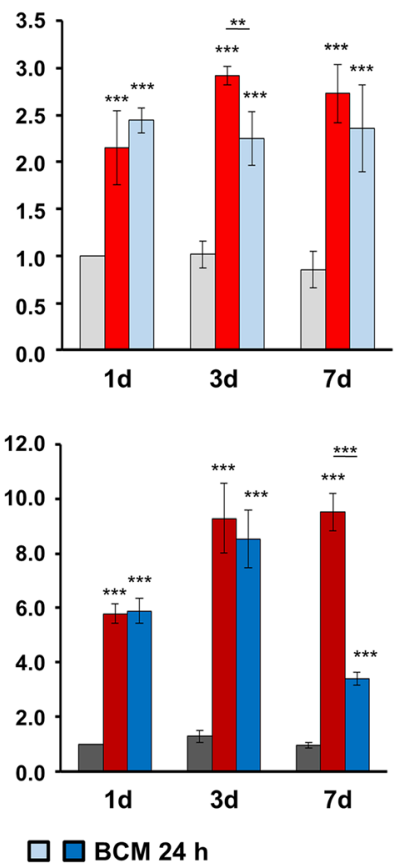
Fig. 5 BCM-coated DBBM induces Alpl gene expression in bone-related cell cultures. $\mathbf{a}, \mathbf{b}$ ST2, MC3T3-E1, and primary bone-derived cells were grown on DBBM coated with BCM-RS (a) or BCM-RS + S (b) for 1, 3, and 7 days before total RNA was isolated and analyzed for the expression of the osteogenic marker gene Alpl by qRT-PCR. Controls (Ctrl) represent cells of each cell type seeded on BCM-free DBBM hydrated with RS (a) or RS + S (b). Values normalized to Gapdh are expressed relative to the values of control cells at the "1 day" time point. Please note the differences in the scales of the $y$-axis. Data represent means \pm SD from three independent experiments. Significant differences to the respective controls at day 1 unless otherwise indicated,

$* * * P<0.001, * * P<0.01$, $* P<0.05$ a

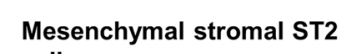
cells

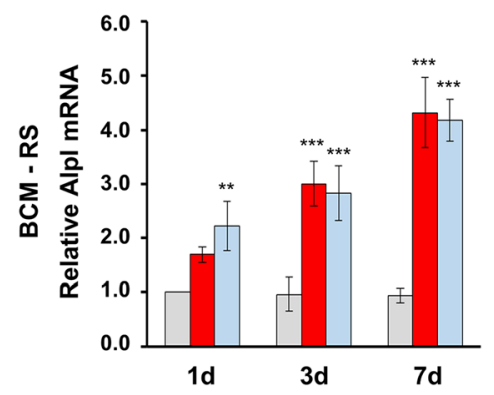

Pre-osteoblastic MC3T3-E1 cells

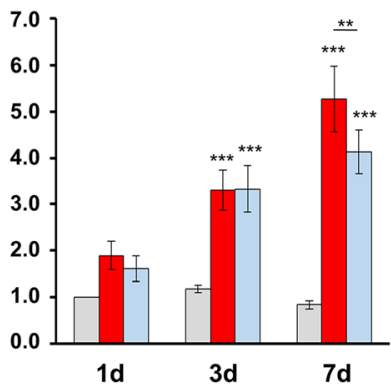

Primary bone-derived cells b

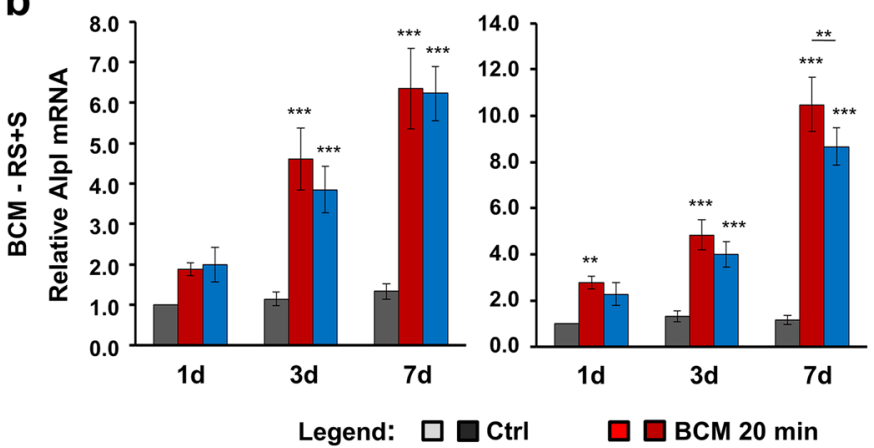

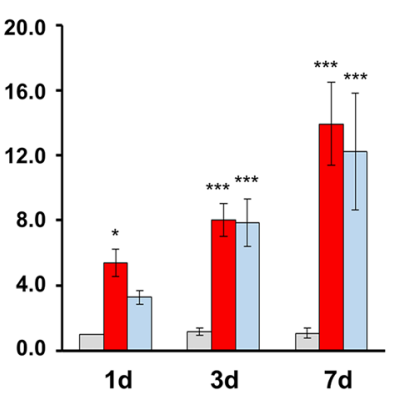

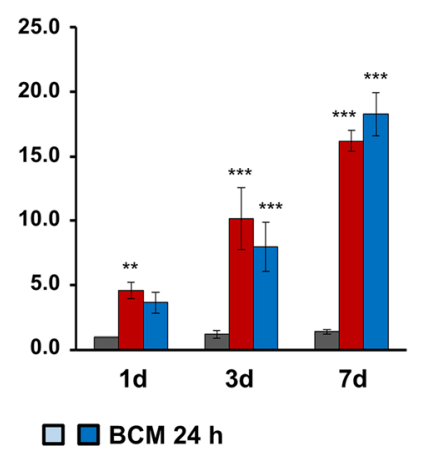

marked a decrease to the expression levels detected on day 1 . In contrast, the expression of Runx 2 generally reached a plateau at day 3, and thus remained high at day 7 (Fig. 4).

Compared to Colla1 and Runx2, Alpl (Fig. 5) and Bglap2 (Fig. 6) genes showed a slightly different pattern of upregulated expression in cells grown on BCM-coated DBBM compared to control cells, with a clear trend of continuous upregulation over 7 days. However, with a small exception for Alpl expression in MC3T3-E1 cells at day 7, we detected no significant differences in the potential of the two BCM preparations ( $20 \mathrm{~min}$ vs. $24 \mathrm{~h}$ ) to upregulate the mRNA levels of the two osteogenic differentiation markers (Figs. 5 and 6).
Fig. 6 BCM-coated DBBM induces Bglap2 gene expression in bone-related cell cultures. $\mathbf{a}, \mathbf{b}$ ST2, MC3T3-E1, and primary bone-derived cells were grown on DBBM coated with BCM-RS (a) or BCM-RS + S (b) for 1, 3, and 7 days before total RNA was extracted and analyzed for the expression of the osteogenic marker gene Bglap2 by qRTPCR. Controls (Ctrl) represent cells of each cell type seeded on BCM-free DBBM hydrated with $\mathrm{RS}$ (a) or RS + S (b). Values normalized to Gapdh are expressed relative to the values of control cells at the time point " 1 day." Please note the differences in the scales of the $y$-axis. Data represent means \pm SD from three independent experiments.

Significant differences to the respective controls at day 1 unless otherwise indicated,

$* * * P<0.001, * * P<0.01$, $* P<0.05$ a

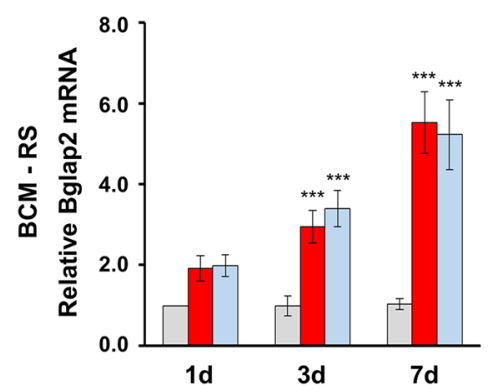

b

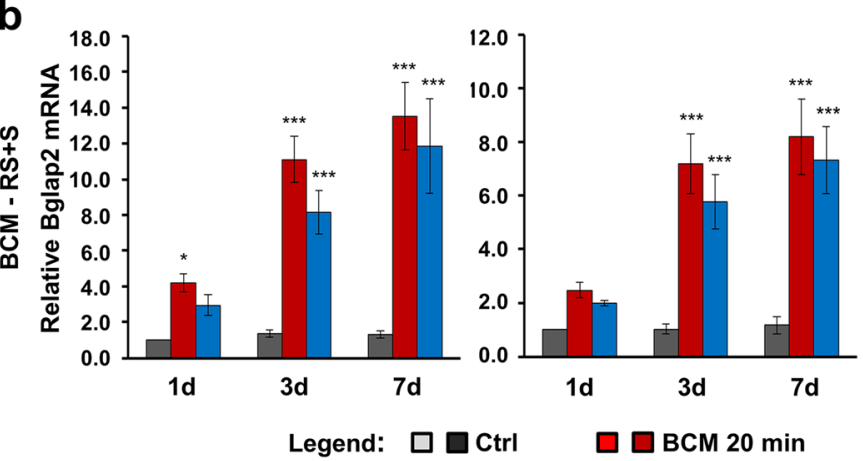

Primary bone-derived cells
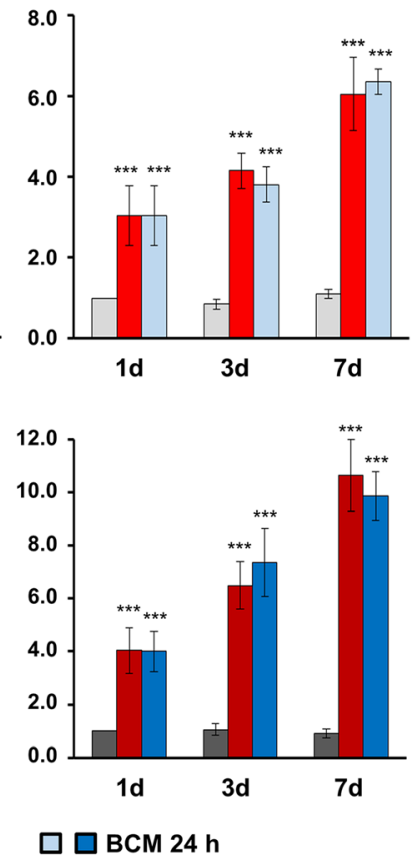
The trend of a higher potency exhibited by the DBBM coated with BCM-RS $+\mathrm{S}$ preparations remained (refer to the difference in the scales between a and b in Figs. 5 and 6).

Altogether, the results suggest that DBBM adsorbs and accumulates factors contained in the BCM that influence both early and late stages of the differentiation process. The process is governed by the upregulated transcription factor Runx2, which characterizes osteoprogenitors and orchestrates the next steps of the osteogenic process, accompanied by the increased expression of Colla1 and Alpl characterizing pre-osteoblasts, and finally by the upregulated osteoblast marker Bglap2.

\section{Additive effect of fresh bone chips and BCM-coated DBBM on the osteogenic differentiation of bone- related cell cultures}

Often, the GBR technique utilizes a combination of autologous bone, DBBM, and a collagen barrier membrane [3, 16-18, 21, 42]. To create an in vitro set-up that mimics as close as possible the clinical situation, we compared the differentiation potential of ST2, MC3T3-E1, and primary bonederived cells grown under four different conditions: (1) control (Ctrl) condition, consisting of cells grown on BCM-free DBBM pre-coated with $\mathrm{RS}+\mathrm{S}$; (2) BCM condition, consisting of cells grown on DBBM coated with the 20-min BCM-RS + S preparation; (3) bone chips (BCh) condition, consisting of cells grown as in (1) but in the presence of fresh bone chips; and (4) BCM/BCh condition, consisting of cells grown in the combined presence of BCM-coated DBBM and fresh bone chips (Fig. 7a). The fresh bone chips in conditions (3) and (4) were placed in a cell culture insert with a $0.4-\mu \mathrm{m}$ pore size, which allows transport of molecules released by the bone chips but no cell migration.

The expression of the osteogenic differentiation markers Colla1 (Fig. 7b), Runx2 (Fig. 7c), Alpl (Fig. 8a), and Bglap2 (Fig. 8b) in cells grown under the above listed conditions for 1, 3, and 7 days was analyzed by qRT-PCR. Generally, both BCM applied as a coating on DBBM (red bars) and fresh bone chips combined with BCM-free DBBM (light green bars) caused increased expression of each of the four differentation markers in all three cell types (Figs. 7 and 8). Interestingly, whereas there were no significant differences between the individual effects of BCM and fresh bone chips, there was an additive and in most of the cases extremely significant $(P<0.001)$ effect of fresh bone chips combined with BCM-coated DBBM on the osteogenic gene expression at all three time points (dark green bars). The combined effect of the fresh bone chips and BCM applied as a coating on the biomaterial appeared to be more than additive on the expression of (1) Colla1 at day 7 in the primary bone-derived cells (Fig. 7b), (2) Runx2 at day 7 in MC3T3-E1 cells (Fig. 7c), (3) Alpl at all three time points in ST2 cells as well as at days 3 and 7 in MC3T3-E1 and primary bone-derived cells (Fig. 8a), and (4) Bglap2 at days 3 and 7 in MC3T3-E1 and the primay bone-derived cells (Fig. 8b). In contrast to Colala gene expression, where the cumulative increase reached a plateau at day 3 (Fig. 7b), we observed a continuous and very significant upregulation in the expression of Runx2 (Fig. 7c), Alpl (Fig. 8a), and Bglap2 (Fig. 8b) over the entire 7-day period.

In summary, the reported data demonstrate a strong additive effect of fresh bone chips combined with BCM-coated DBBM on the osteogenic differentiation of the three cell types utilized in the present study. This justifies the simultaneous application of BCM-coated DBBM and autologous bone chips leading to the complete utilization of the osteoinductive properties of the autograft.

\section{Discussion}

DBBM is a calcium phosphate-based bone substitute of natural origin, widely used in dental surgery for bone augmentation procedures and for the treatment of periodontal and periimplant bone defects [43-45]. By nature, DBBM is a bovine bone undergoing a chemical extraction process at low heat $\left(300{ }^{\circ} \mathrm{C}\right.$ ) for removing existing organic components while the natural architecture of bone remains preserved [46]. Whereas some alloplastic materials exhibit considerably high elastic moduli, DBBM has an elastic modulus close to that of mandibular cortical bone [47, 48]. In vivo, it is nearly nonresorbable [49]. DBBM is one of the most researched bone grafting materials, which has demonstrated excellent osteoconductive properties positively influencing the bone regeneration [50-52]. Furthermore, it has been shown to successfully adsorb a variety of proteins, including BMPs, thus generating favorable microenvironment for migrating mesenchymal stem cells and osteoprogenitors [53, 54]. Aiming to maximize the adsorption of factors released in the BCM to a bone grafting material, we made the choice to utilize DBBM in the current in vitro study. Previous studies have demonstrated that a 24-h extraction of cortical bone chips of porcine origin with cell culture media contains a large spectrum of proteins (more than 150) [6] possessing the potential to target cellular processes in various cell types playing a role in the graft consolidation process [7-9, 32]. In particular, the BCM improved oral fibroblast cell activity $[7,8]$ as well as induced osteoclastogenesis in bone marrow cultures [9]. It can be suggested that BCM resembles other autogenous growth factor sources such as platelet-rich fibrin (PRF) or platelet-rich plasma (PRP). However, a number of studies have shown a limited ability of the platelet concentrates to induce bone formation [55-58]. This may be explained by the fact that the growth factors contained in PRF and PRP originate from whole blood, whereas BCM represents an autologous growth factor-rich medium originating from bone tissue and aiming to accelerate the regeneration of the same tissue. Therefore, 
a

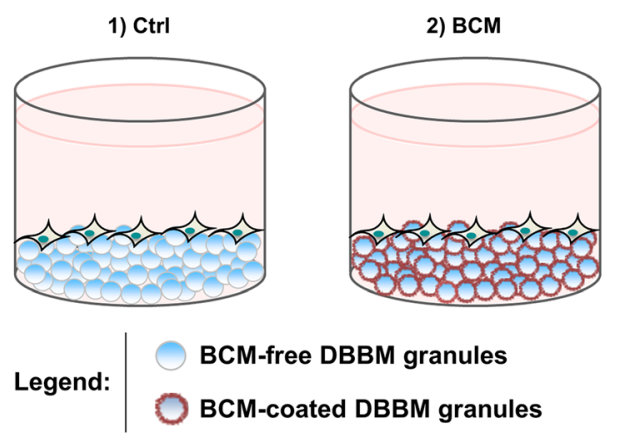

3) $\mathrm{BCh}$

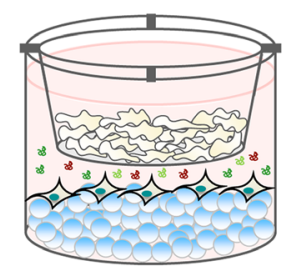

$\approx$ BCh (Bone Chips)

Molecules released by $\mathrm{BCh}$
4) $\mathrm{BCM} / \mathrm{BCh}$

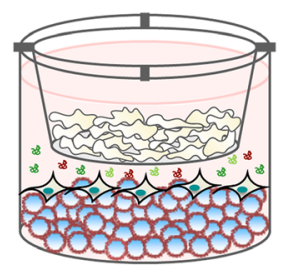

Cells b
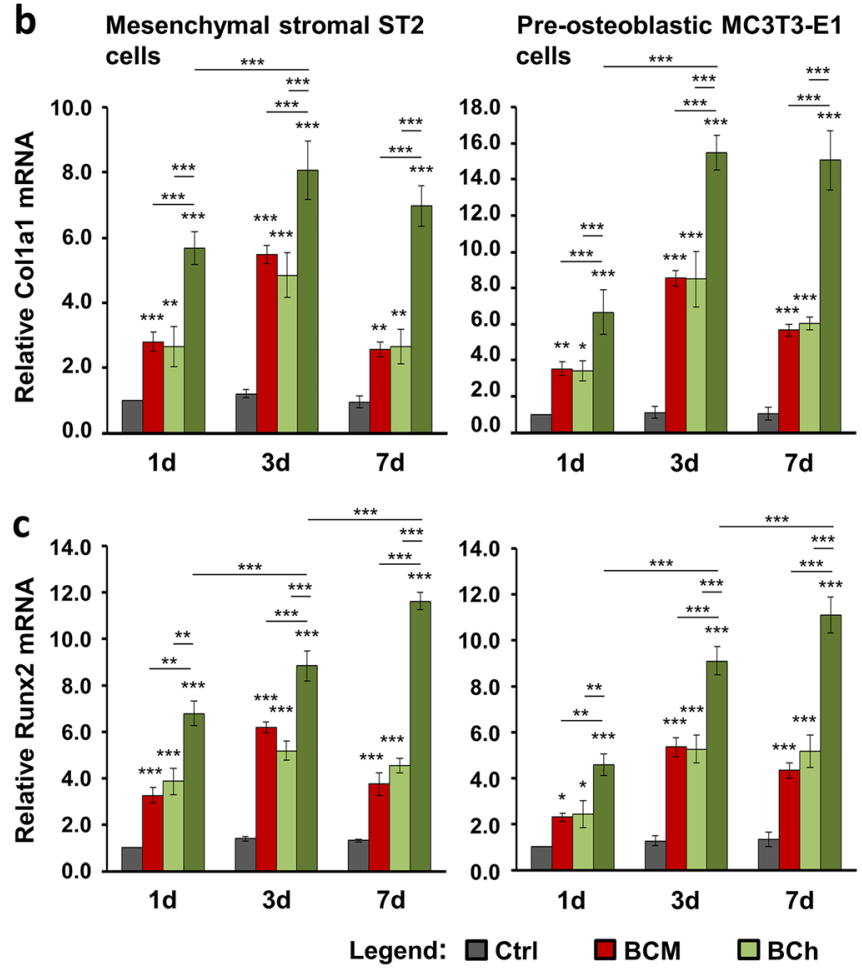
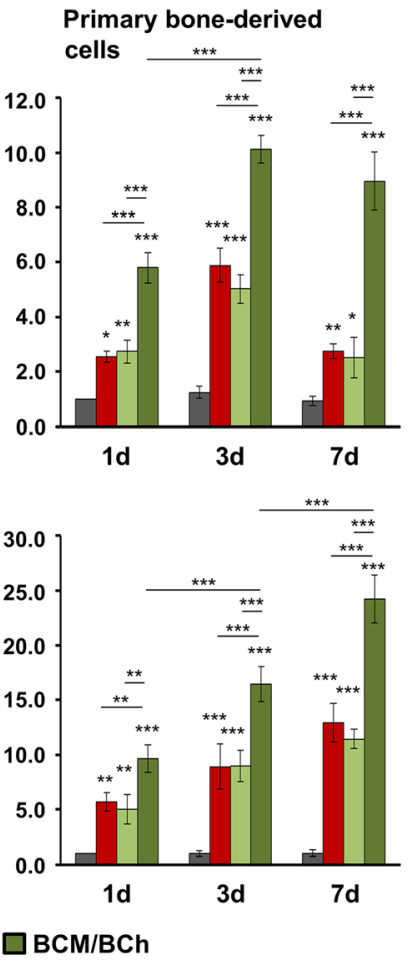

Fig. 7 Additive effect of fresh bone chips and BCM-coated DBBM on the Col1a1 and Runx2 gene expression in bone-related cell cultures. a Schematic representation of the four experimental conditions, which are compared in (b). ST2, MC3T3-E1, and primary bone-derived cells are grown for 1, 3, and 7 days either on (1) BCM-free DBBM granules hydrated with $\mathrm{RS}+\mathrm{S}$, a condition labeled as control (Ctrl) or (2) DBBM granules coated with BCM prepared within 20 min in $\mathrm{RS}+\mathrm{S}$, a condition labeled as BCM. Experimental conditions (3) bone chips ( $\mathrm{BCh}$ ) and (4) $\mathrm{BCM} / \mathrm{BCh}$ duplicate conditions (1) and (2) in the presence of fresh bone chips placed in a cell culture insert with a $0.4-\mu \mathrm{m}$ pore size.

BCM is thought to exhibit a specific activity in bone augmentation. Indeed, it has been proven that BCM triggers a prominent response of TGF- $\beta$ signaling pathways by modulating the expression of adrenomedulin (ADM), pentraxin 3 (PTX3), $\mathrm{BTB} / \mathrm{POZ}$ domain-containing protein 11 (BTBD11), interleukin-11 (IL-11), NADPH oxidase 4 (NOX4), and proteoglycan 4 (PRG4), all known downstream regulators of the TGF- $\beta$ signaling cascade [8]. Various functions associated with bone metabolism and graft consolidation have been b, c Effect of BCM-coated DBBM in the absence or presence of fresh bone chips on Col1a1 (b) and Runx2 (c) mRNA expression levels in ST2, MC3T3-E1, and primary bone-derived cells. Cells were grown under each of the four experimental conditions described in (a) for 1, 3, and 7 days before total RNA was isolated and analyzed by qRT-PCR. Values normalized to Gapdh are expressed relative to the values of control cells at the " 1 day" time point. Please note the differences in the scales of the $y$ axis. Data represent means \pm SD from three independent experiments. Significant differences to the respective controls at day 1 unless otherwise indicated, $* * * P<0.001, * * P<0.01, * P<0.05$

reported for each of the genes in this panel [8]. Moreover, our most recent research identifies TGF- $\beta 1$ and BMP-2, two growth factors with a specific activity in bone regeneration, as major constituents of BCM [33]. Most importantly, a fast and significant release of TGF- $\beta 1$ from autogenous bone was detected within $10 \mathrm{~min}$ and a specific crosstalk between TGF- $\beta 1$ and BMP-2 was pointed as the mechanism by which BCM exerts its activity on the osteogenic differentiation of mesenchymal stromal cells [33]. 
Fig. 8 Additive effect of fresh bone chips and BCM-coated DBBM on the Alpl and Bglap2 gene expression in bone-related cell cultures. a, $\mathbf{b}$ Effect of BCMcoated DBBM in the absence or presence of fresh bone chips on Alpl (a) and Bglap2 (b) mRNA levels in ST2, MC3T3-E1, and primary bone-derived cells. Cells were grown under each of the four experimental conditions described in Fig. 7a for 1, 3, and 7 days before total RNA was extracted and analyzed by qRTPCR. Values normalized to Gapdh are expressed relative to the values of control cells at the time point " 1 day." Please note the differences in the scales of the $y$-axis. Data represent means \pm SD from three independent experiments. Significant differences to the respective controls at day 1 unless otherwise indicated, $* * * P<0.001, * * P<0.01$, $* P<0.05$
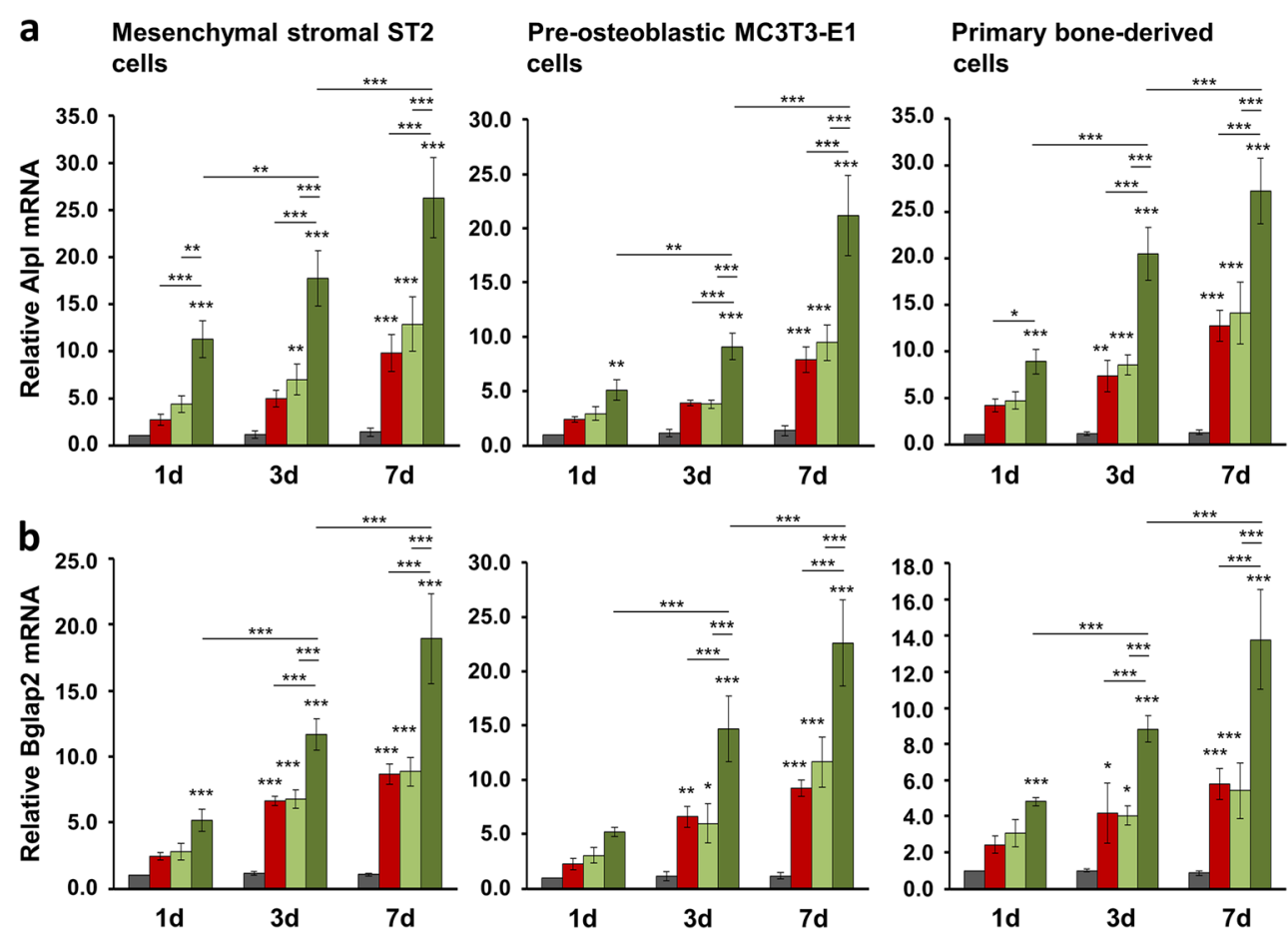

Legend: cells
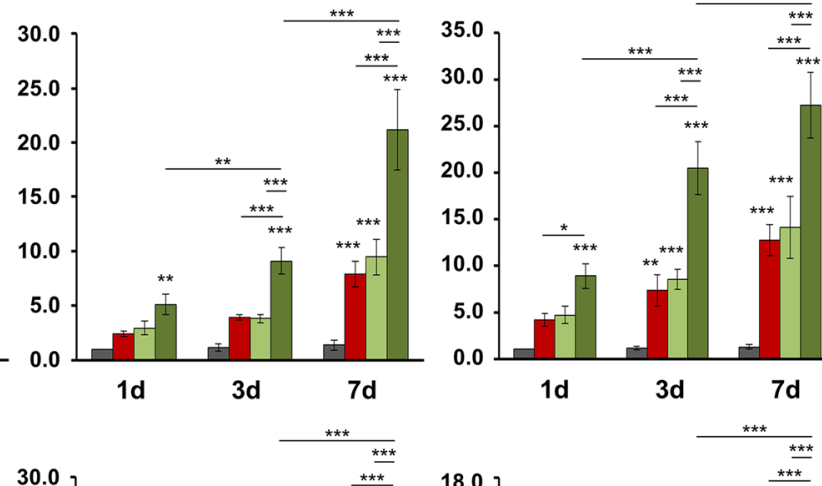

Thus, the goal of the current study was to take a next step in investigating the biological activity of BCM by combining it with DBBM. Our data strongly suggest that bio-activation of osteoconductive bone substitutes with a short-term extracted $\mathrm{BCM}$ is possible. Osteogenesis is characterized by recruitment of osteoprogenitors, their attachment, proliferation, and differentiation into mature osteoblasts [59]. Indeed, bone-related cell types grown on DBBM coated with BCM, which was prepared within a clinically relevant time window of $20 \mathrm{~min}$, exhibited increased adhesive, proliferative, and differentiation properties. To the best of our knowledge, this is the first study that gives a rationale for the fast preparation of BCM during the surgical implant bed preparation and its application for coating of biomaterials. Moreover, we observed an additive, nearly synergistic effect of fresh bone chips combined with BCM-coated DBBM on the osteogenic differentiation of the three cell types utilized in the study. This further supports the simultaneous application of BCM-coated DBBM and autologous bone chips in GBR procedures. In comparison to the present study where BCM was applied as a coating on DBBM, it is interesting to note that an opposing effect of BCM on the osteogenic differentiation of ST2 cells was observed with BCM applied in suspension, in the absence of a biomaterial [31, 33]. This observation was valid for both BCM preparations, 20-min and 24-h. Peng et al. detected decreased alkaline phosphatase activity and mRNA expression in ST2 cells treated with a 24-h BCM preparation [31], and we observed an inhibitory effect of the 20-min BCM preparation applied in suspension on the expression of late osteogenic markers [33]. We can thus speculate that proteins contained in the BCM may exhibit differential confirmation when coated on DBBM or another biomaterial. This new confirmation may be differentially recognized by transmembrane receptors on the cell surface leading to activation of signaling pathways different from the ones activated by proteins contained in a suspension. Altogether, our data strongly support a clinical approach combining the excellent adsorption and osteoconductive properties of the DBBM with two sources of autogenous growth factors, namely BCM and autologous bone chips. Furthermore, BCM is extracted in a mixture of Ringer's solution and patient blood, which adds the activity of factors from yet a third autogenous source to the BCM. Indeed, BCM-RS $+\mathrm{S}$ preparations were more potent in inducing the osteogenic differentiation of the tested cell types. $\mathrm{RS}+\mathrm{S}$ in itself was enough to stimulate cellular proliferation but not osteogenesis. The topic of blood coating of biomaterials is poorly investigated and deserves further attention. A study reports differential positive effects of titanium implant surface coating with different blood components on the proliferative potential of human osteoblasts [60]. The differences that we observed in the effects caused by the DBBM coated with the 20-min or the 24-h BCM preparation were with variable significance for the various cellular functionalities tested in the study. This may be attributed to the specific protein content and protein stability of the different BCM preparations and deserves further investigation.

A number of studies have reported combination approaches utilizing bone substitutes and recombinant growth factors. BMP-2, BMP-7, platelet-derived growth factor 
(PDGF), fibroblast growth factor-2 (FGF-2), and growth and differentiation factor-5 (GDF-5) are among the growth factors commonly researched and utilized in regenerative dentistry [61-67]. Terheyden et al. combined DBBM of the same type as the used in the current study with BMP-7 and compared this combination with DBBM alone in maxillary sinus floor grafting in pigs [61]. The authors reported that significant amounts of new bone were generated in both groups with the important exception that the BMP-7-coated DBBM group resulted in faster apposition and better quality of bone. Shortcomings of utilizing recombinant growth factors for clinical practice have been their short half-lives, instability and fast degradation rates, side effects, and not on a last place poor cost-effectiveness [68-71].

The approach of utilizing a combination of BCM-coated DBBM and autologous bone chips, described in the current study, would revoke the necessity of extracting a huge amount of autologous bone chips allowing an intraoral rather than an extraoral donor site to be used for autograft harvesting. This will further decrease the postoperative morbidity at the patient donor site and contribute to a reduced healing time. Combined with previous findings about the biological activity of the $\mathrm{BCM}$ [33], the current study represents the first steps towards the establishment of an in vitro-tested standard procedure for generation of BCM as well as for pre-coating of DBBM with it, within the limited time for the surgical tooth bed preparation.

A limitation of the present study is the use of BCM of porcine origin. Future research employing transcriptomics and proteomics analyses of RNA and protein extracted from cells grown on DBBM coated with human BCM is needed in order to determine the genes, on a genome-wide base, whose expression have been modulated in response to short-term extracted human BCM. These additional investigations would supplement the data presented in the current study by investigating the signaling pathways of osteogenesis triggered by the BCM-activated biomaterial. Furthermore, recommendation stemming from in vitro studies in the form of a protocol for the preparation of $\mathrm{BCM}$ and its application for biofunctionalization of DBBM in GBR procedures would need an animal testing in vivo. Such studies will determine whether BCM combined with a bone grafting material may be a superior candidate for bone regeneration procedures than the individual recombinant growth factors combined with the respective bone graft.

In summary, the presented in vitro study clearly demonstrates that biological pre-activation of DBBM with BCM, extracted within a clinically relevant time window of $20 \mathrm{~min}$, is feasible and may appear as an optimal modality in the treatment of both regular and complex bone defects.

Acknowledgments We thank Catherine Solioz and Anne-Flore Hämmerli for their technical assistance and Jordi Caballé-Serrano for harvesting of porcine bone chips.
Author contributions MBA, VC, and DB contributed to the study conception and design. Data acquisition was performed by LP. Data analyses and interpretation were performed by MBA with contributions from all authors. The first draft of the manuscript was written by MBA with the help of LP, and all authors commented on previous versions of the manuscript. All authors read and approved the final manuscript.

Funding Open access funding provided by University of Bern. The work was supported by Geistlich Pharma and the Research Scholarship Program of the Osteology Foundation, Switzerland.

Data availability All data generated and analyzed during this study are included in this article and its Electronic Supplementary Material file.

\section{Compliance with ethical standards}

Conflict of interest The authors declare that they have no conflict of interest.

Ethical approval This study was performed in line with the principles of the Declaration of Helsinki. Approval was granted by the Swiss Ethics Committees on research involving humans (13.08.2018/No. 201800661).

Informed consent Written informed consent was obtained from the patients.

Open Access This article is licensed under a Creative Commons Attribution 4.0 International License, which permits use, sharing, adaptation, distribution and reproduction in any medium or format, as long as you give appropriate credit to the original author(s) and the source, provide a link to the Creative Commons licence, and indicate if changes were made. The images or other third party material in this article are included in the article's Creative Commons licence, unless indicated otherwise in a credit line to the material. If material is not included in the article's Creative Commons licence and your intended use is not permitted by statutory regulation or exceeds the permitted use, you will need to obtain permission directly from the copyright holder. To view a copy of this licence, visit http://creativecommons.org/licenses/by/4.0/.

\section{References}

1. Kao ST, Scott DD (2007) A review of bone substitutes. Oral Maxillofac Surg Clin North Am 19(4):513-521, vi. https://doi. org/10.1016/j.coms.2007.06.002

2. Chiapasco M, Casentini P, Zaniboni M (2009) Bone augmentation procedures in implant dentistry. Int J Oral Maxillofac Implants 24: 237-259

3. Buser D, Chappuis V, Kuchler U, Bornstein MM, Wittneben JG, Buser R, Cavusoglu Y, Belser UC (2013) Long-term stability of early implant placement with contour augmentation. J Dent Res 92(12 Suppl):176S-182S. https://doi.org/10.1177/ 0022034513504949

4. Campana V, Milano G, Pagano E, Barba M, Cicione C, Salonna G, Lattanzi W, Logroscino G (2014) Bone substitutes in orthopaedic surgery: from basic science to clinical practice. J Mater Sci Mater Med 25(10):2445-2461. https:// doi.org/10.1007/s10856-014-5240-2

5. Stern A, Barzani G (2015) Autogenous bone harvest for implant reconstruction. Dent Clin N Am 59(2):409-420. https://doi.org/10. 1016/j.cden.2014.10.011 
6. Caballé-Serrano J, Bosshardt DD, Buser D, Gruber R (2014) Proteomic analysis of porcine bone-conditioned medium. Int $\mathrm{J}$ Oral Maxillofac Implants 29(5):1208-1215d

7. Filho GS, Caballé-Serrano J, Sawada K, Bosshardt DD, Bianchini MA, Buser D, Gruber R (2015) Conditioned medium of demineralized freeze-dried bone activates gene expression in periodontal fibroblasts in vitro. J Periodontol 86(6):827-834. https:// doi.org/10.1902/jop.2015.140676

8. Zimmermann M, Caballé-Serrano J, Bosshardt D, Ankersmit H, Buser D, Gruber R (2015) Bone-conditioned medium changes gene expression in bone-derived fibroblasts. Int J Oral Maxillofac Implants 30(4):953-958

9. Caballé-Serrano J, Filho GS, Bosshardt DD, Gargallo-Albiol J, Buser D, Gruber R (2016) Conditioned medium from fresh and demineralized bone enhances osteoclastogenesis in murine bone marrow cultures. Clin Oral Implants Res 27(2):226-232. https:// doi.org/10.1111/clr.12573

10. Hallman M, Lundgren S, Sennerby L (2001) Histologic analysis of clinical biopsies taken 6 months and 3 years after maxillary sinus floor augmentation with $80 \%$ bovine hydroxyapatite and $20 \%$ autogenous bone mixed with fibrin glue. Clin Implant Dent Relat Res 3(2):87-96. https://doi.org/10.1111/j.1708-8208.2001.tb00236.x

11. Nkenke E, Radespiel-Tröger M, Wiltfang J, Schultze-Mosgau S, Winkler G, Neukam FW (2002) Morbidity of harvesting of retromolar bone grafts: a prospective study. Clin Oral Implants Res 13(5):514-521. https://doi.org/10.1034/j.1600-0501.2002. 130511.x

12. Cricchio G, Lundgren S (2003) Donor site morbidity in two different approaches to anterior iliac crest bone harvesting. Clin Implant Dent Relat Res 5(3):161-169. https://doi.org/10.1111/j.1708-8208. 2003.tb00198.x

13. Dahlin C, Linde A, Gottlow J, Nyman S (1988) Healing of bone defects by guided tissue regeneration. Plast Reconstr Surg 81(5): 672-676. https://doi.org/10.1097/00006534-198805000-00004

14. Dahlin C, Gottlow J, Linde A, Nyman S (1990) Healing of maxillary and mandibular bone defects using a membrane technique. An experimental study in monkeys. Scand J Plast Reconstr Surg Hand Surg 24(1):13-19. https://doi.org/10.3109/02844319009004514

15. Schenk RK, Buser D, Hardwick WR, Dahlin C (1994) Healing pattern of bone regeneration in membrane-protected defects: a histologic study in the canine mandible. Int J Oral Maxillofac Implants 9(1):13-29

16. Buser D, Chen ST, Weber HP, Belser UC (2008) Early implant placement following single-tooth extraction in the esthetic zone: biologic rationale and surgical procedures. Int J Periodontics Restorative Dent 28(5):441-451

17. Buser D, Chappuis V, Bornstein MM, Wittneben J-G, Frei M, Belser UC (2013) Long-term stability of contour augmentation with early implant placement following single tooth extraction in the esthetic zone: a prospective, cross-sectional study in 41 patients with a 5- to 9-year follow-up. J Periodontol 84(11):1517-1527. https://doi.org/10.1902/jop.2013.120635

18. Jensen SS, Bosshardt DD, Gruber R, Buser D (2014) Long-term stability of contour augmentation in the esthetic zone: histologic and histomorphometric evaluation of 12 human biopsies 14 to 80 months after augmentation. J Periodontol 85(11):1549-1556. https://doi.org/10.1902/jop.2014.140182

19. Urban IA, Nagursky H, Lozada JL, Nagy K (2013) Horizontal ridge augmentation with a collagen membrane and a combination of particulated autogenous bone and anorganic bovine bone-derived mineral: a prospective case series in 25 patients. Int J Periodontics Restorative Dent 33(3):299-307. https://doi.org/10.11607/prd. 1407

20. Urban IA, Lozada JL, Jovanovic SA, Nagursky H, Nagy K (2014) Vertical ridge augmentation with titanium-reinforced, dense-PTFE membranes and a combination of particulated autogenous bone and anorganic bovine bone-derived mineral: a prospective case series in 19 patients. Int J Oral Maxillofac Implants 29(1):185-193. https:// doi.org/10.11607/jomi.3346

21. Bornstein MM, Chappuis V, Von Arx T, Buser D (2008) Performance of dental implants after staged sinus floor elevation procedures: 5-year results of a prospective study in partially edentulous patients. Clin Oral Implants Res 19(10):1034-1043. https:// doi.org/10.1111/j.1600-0501.2008.01573.x

22. Jensen SS, Bornstein MM, Dard M, Bosshardt DD, Buser D (2009) Comparative study of biphasic calcium phosphates with different $\mathrm{HA} / \mathrm{TCP}$ ratios in mandibular bone defects. A long-term histomorphometric study in minipigs. J Biomed Mater Res B Appl Biomater 90B(1):171-181. https://doi.org/10.1002/jbm.b. 31271

23. Klinge B, Alberius P, Isaksson S, Jönsson J (1992) Osseous response to implanted natural bone mineral and synthetic hydroxylapatite ceramic in the repair of experimental skull bone defects. J Oral Maxillofac Surg 50(3):241-249. https://doi.org/10.1016/ 0278-2391(92)90320-y

24. Cordaro L, Bosshardt DD, Palattella P, Rao W, Serino G, Chiapasco M (2008) Maxillary sinus grafting with Bio-Oss or Straumann Bone Ceramic: histomorphometric results from a randomized controlled multicenter clinical trial. Clin Oral Implants Res 19(8):796-803. https://doi.org/10.1111/j.1600-0501.2008. 01565.x

25. Cohen RE, Mullarky RH, Noble B, Comeau RL, Neiders ME (1994) Phenotypic characterization of mononuclear cells following anorganic bovine bone implantation in rats. J Periodontol 65(11): 1008-1015. https://doi.org/10.1902/jop.1994.65.11.1008

26. Yildirim M, Spiekermann H, Biesterfeld S, Edelhoff D (2000) Maxillary sinus augmentation using xenogenic bone substitute material Bio-Oss in combination with venous blood. A histologic and histomorphometric study in humans. Clin Oral Implants Res 11(3): 217-229. https://doi.org/10.1034/j.1600-0501.2000.011003217.x

27. Caballé-Serrano J, Fujioka-Kobayashi M, Bosshardt DD, Gruber R, Buser D, Miron RJ (2016) Pre-coating deproteinized bovine bone mineral (DBBM) with bone-conditioned medium (BCM) improves osteoblast migration, adhesion, and differentiation in vitro. Clin Oral Investig 20(9):2507-2513. https://doi.org/10.1007/s00784016-1747-x

28. Caballé-Serrano J, Sawada K, Miron RJ, Bosshardt DD, Buser D, Gruber R (2017) Collagen barrier membranes adsorb growth factors liberated from autogenous bone chips. Clin Oral Implants Res 28(2):236-241. https://doi.org/10.1111/clr.12789

29. Kuchler U, Rybaczek T, Dobask T, Heimel P, Tangl S, Klehm J, Menzel M, Gruber R (2018) Bone-conditioned medium modulates the osteoconductive properties of collagen membranes in a rat calvaria defect model. Clin Oral Implants Res 29(4):381-388. https://doi.org/10.1111/clr.13133

30. Caballé-Serrano J, Sawada K, Filho GS, Bosshardt DD, Buser D, Gruber R (2015) Bone conditioned medium: preparation and bioassay. J Vis Exp 101:e52707. https://doi.org/10.3791/52707

31. Peng J, Nemec M, Brolese E, Bosshardt DD, Schaller B, Buser D, Gruber R (2015) Bone-conditioned medium inhibits osteogenic and adipogenic differentiation of mesenchymal cells in vitro. Clin Implant Dent Relat Res 17(5):938-949. https://doi.org/10.1111/ cid. 12200

32. Brolese E, Buser D, Kuchler U, Schaller B, Gruber R (2015) Human bone chips release of sclerostin and FGF-23 into the culture medium: an in vitro pilot study. Clin Oral Implants Res 26(10): 1211-1214. https://doi.org/10.1111/clr.12432

33. Asparuhova MB, Caballé-Serrano J, Buser D, Chappuis V (2018) Bone-conditioned medium contributes to initiation and progression of osteogenesis by exhibiting synergistic TGF- $\beta 1$ /BMP-2 activity. Int J Oral Sci 10(2):20. https://doi.org/10.1038/s41368-018-0021-2 
34. Miron RJ, Gruber R, Hedbom E, Saulacic N, Zhang Y, Sculean A, Bosshardt DD, Buser D (2013) Impact of bone harvesting techniques on cell viability and the release of growth factors of autografts. Clin Implant Dent Relat Res 15(4):481-489. https://doi.org/ 10.1111/j.1708-8208.2012.00440.x

35. Miron RJ, Hedbom E, Saulacic N, Zhang Y, Sculean A, Bosshardt DD, Buser D (2011) Osteogenic potential of autogenous bone grafts harvested with four different surgical techniques. J Dent Res 90(12):1428-1433. https://doi.org/10.1177/ 0022034511422718

36. Saulacic N, Bosshardt DD, Jensen SS, Miron RJ, Gruber R, Buser D (2015) Impact of bone graft harvesting techniques on bone formation and graft resorption: a histomorphometric study in the mandibles of minipigs. Clin Oral Implants Res 26(4):383-391. https:// doi.org/10.1111/clr.12357

37. Bakker AD, Klein-Nulend J (2012) Osteoblast isolation from murine calvaria and long bones. Methods Mol Biol 816:19-29. https:// doi.org/10.1007/978-1-61779-415-5_2

38. Bonewald LF (2011) The amazing osteocyte. J Bone Miner Res 26(2):229-238. https://doi.org/10.1002/jbmr.320

39. Capulli M, Paone R, Rucci N (2014) Osteoblast and osteocyte: games without frontiers. Arch Biochem Biophys 561:3-12. https://doi.org/10.1016/j.abb.2014.05.003

40. Gurbuz I, Ferralli J, Roloff T, Chiquet-Ehrismann R, Asparuhova MB (2014) SAP domain-dependent Mkl1 signaling stimulates proliferation and cell migration by induction of a distinct gene set indicative of poor prognosis in breast cancer patients. Mol Cancer 13:22-22. https://doi.org/10.1186/1476-4598-13-22

41. Livak KJ, Schmittgen TD (2001) Analysis of relative gene expression data using real-time quantitative PCR and the 2(-Delta Delta $\mathrm{C}(\mathrm{T}))$ method. Methods 25(4):402-408

42. Von Arx T, Buser D (2006) Horizontal ridge augmentation using autogenous block grafts and the guided bone regeneration technique with collagen membranes: a clinical study with 42 patients. Clin Oral Implants Res 17(4):359-366. https://doi.org/10.1111/j. 1600-0501.2005.01234.x

43. Mardas N, Chadha V, Donos N (2010) Alveolar ridge preservation with guided bone regeneration and a synthetic bone substitute or a bovine-derived xenograft: a randomized, controlled clinical trial. Clin Oral Implants Res 21(7):688-698. https://doi.org/10.1111/j. 1600-0501.2010.01918.x

44. Lindgren C, Mordenfeld A, Hallman M (2012) A prospective 1 -year clinical and radiographic study of implants placed after maxillary sinus floor augmentation with synthetic biphasic calcium phosphate or deproteinized bovine bone. Clin Implant Dent Relat Res 14(1):41-50. https://doi.org/10. 1111/j.1708-8208.2010.00224.x

45. Schmitt CM, Doering H, Schmidt T, Lutz R, Neukam FW, Schlegel KA (2013) Histological results after maxillary sinus augmentation with Straumann ${ }^{\circledR}$ BoneCeramic, Bio-Oss ${ }^{\circledR}$, Puros ${ }^{\circledR}$, and autologous bone. A randomized controlled clinical trial. Clin Oral Implants Res 24(5):576-585. https://doi.org/10.1111/j.1600-0501. 2012.02431.x

46. Rosen VB, Hobbs LW, Spector M (2002) The ultrastructure of anorganic bovine bone and selected synthetic hyroxyapatites used as bone graft substitute materials. Biomaterials 23(3):921-928. https://doi.org/10.1016/s0142-9612(01)00204-6

47. Amaral M, Lopes MA, Silva RF, Santos JD (2002) Densification route and mechanical properties of Si3N4-bioglass biocomposites. Biomaterials 23(3):857-862. https://doi.org/10.1016/S01429612(01)00194-6

48. Liang L, Rulis P, Ching WY (2010) Mechanical properties, electronic structure and bonding of $\alpha$ - and $\beta$-tricalcium phosphates with surface characterization. Acta Biomater 6(9):3763-3771. https://doi.org/10.1016/j.actbio.2010.03.033
49. Araújo MG, Carmagnola D, Berglundh T, Thilander B, Lindhe J (2001) Orthodontic movement in bone defects augmented with Bio-Oss. An experimental study in dogs. J Clin Periodontol 28(1): 73-80. https://doi.org/10.1034/j.1600-051x.2001.280111.x

50. Baldini N, De Sanctis M, Ferrari M (2011) Deproteinized bovine bone in periodontal and implant surgery. Dent Mater 27(1):61-70. https://doi.org/10.1016/j.dental.2010.10.017

51. Hassan KS, Marei HF, Alagl AS (2011) Composite bone graft for treatment of osseous defects after surgical removal of impacted third and second molars: case report and review of the literature. Oral Surg Oral Med Oral Pathol Oral Radiol Endod 112(6):e8-e15. https://doi.org/10.1016/j.tripleo.2011.04.010

52. Jensen T, Schou S, Stavropoulos A, Terheyden H, Holmstrup P (2012) Maxillary sinus floor augmentation with Bio-Oss or BioOss mixed with autogenous bone as graft in animals: a systematic review. Int J Oral Maxillofac Surg 41(1):114-120. https://doi.org/ 10.1016/j.ijom.2011.08.010

53. Thoma DS, Kruse A, Ghayor C, Jung RE, Weber FE (2015) Bone augmentation using a synthetic hydroxyapatite/silica oxide-based and a xenogenic hydroxyapatite-based bone substitute materials with and without recombinant human bone morphogenetic protein-2. Clin Oral Implants Res 26(5):592-598. https://doi.org/10. 1111/clr.12469

54. Miron RJ, Bosshardt DD, Buser D, Zhang Y, Tugulu S, Gemperli A, Dard M, Caluseru OM, Chandad F, Sculean A (2015) Comparison of the capacity of enamel matrix derivative gel and enamel matrix derivative in liquid formulation to adsorb to bone grafting materials. J Periodontol 86(4):578-587. https://doi.org/10. 1902/jop.2015.140538

55. Ocak H, Kutuk N, Demetoglu U, Balcioglu E, Ozdamar S, Alkan A (2017) Comparison of bovine bone-autogenic bone mixture versus platelet-rich fibrin for maxillary sinus grafting: histologic and histomorphologic study. J Oral Implantol 43(3):194-201. https:// doi.org/10.1563/aaid-joi-D-16-00104

56. Kumar YR, Mohanty S, Verma M, Kaur RR, Bhatia P, Kumar VR, Chaudhary Z (2016) Platelet-rich fibrin: the benefits. Br J Oral Maxillofac Surg 54(1):57-61. https://doi.org/10.1016/j.bjoms. 2015.10.015

57. Joseph VR, Sam G, Amol NV (2014) Clinical evaluation of autologous platelet rich fibrin in horizontal alveolar bony defects. J Clin Diagn Res 8(11):Zc43-Zc47. https://doi.org/10.7860/jcdr/2014/ 9948.5129

58. Dutta SR, Passi D, Singh P, Sharma S, Singh M, Srivastava D (2016) A randomized comparative prospective study of plateletrich plasma, platelet-rich fibrin, and hydroxyapatite as a graft material for mandibular third molar extraction socket healing. Natl $\mathrm{J}$ Maxillofac Surg 7(1):45-51. https://doi.org/10.4103/0975-5950. 196124

59. Teti A (2011) Bone development: overview of bone cells and signaling. Curr Osteoporos Rep 9(4):264-273. https://doi.org/10. 1007/s11914-011-0078-8

60. Himmlova L, Kubies D, Hulejova H, Bartova J, Riedel T, Stikarova J, Suttnar J, Pesakova V (2016) Effect of blood component coatings of enosseal implants on proliferation and synthetic activity of human osteoblasts and cytokine production of peripheral blood mononuclear cells. Mediat Inflamm 2016:8769347-8769315. https://doi. org/10.1155/2016/8769347

61. Terheyden H, Jepsen S, Möller B, Tucker MM, Rueger DC (1999) Sinus floor augmentation with simultaneous placement of dental implants using a combination of deproteinized bone xenografts and recombinant human osteogenic protein-1. A histometric study in miniature pigs. Clin Oral Implants Res 10(6):510-521. https:// doi.org/10.1034/j.1600-0501.1999.100609.x

62. Jung RE, Glauser R, Schärer P, Hämmerle CH, Sailer HF, Weber FE (2003) Effect of rhBMP-2 on guided bone regeneration in 
humans. Clin Oral Implants Res 14(5):556-568. https://doi.org/10. 1034/j.1600-0501.2003.00921.x

63. Nevins M, Camelo M, Nevins ML, Schenk RK, Lynch SE (2003) Periodontal regeneration in humans using recombinant human platelet-derived growth factor-BB (rhPDGF-BB) and allogenic bone. J Periodontol 74(9):1282-1292. https://doi.org/10.1902/jop. 2003.74.9.1282

64. Gruber RM, Ludwig A, Merten H-A, Achilles M, Poehling S, Schliephake H (2008) Sinus floor augmentation with recombinant human growth and differentiation factor-5 (rhGDF-5): a histological and histomorphometric study in the Goettingen miniature pig. Clin Oral Implants Res 19(5):522-529. https://doi.org/10.1111/j. 1600-0501.2007.01494.x

65. Schwarz F, Rothamel D, Herten M, Ferrari D, Sager M, Becker J (2008) Lateral ridge augmentation using particulated or block bone substitutes biocoated with rhGDF-5 and rhBMP-2: an immunohistochemical study in dogs. Clin Oral Implants Res 19(7):642-652. https://doi.org/10.1111/j.1600-0501.2008.01537.x

66. Kitamura M, Akamatsu M, Machigashira M, Hara $Y$, Sakagami R, Hirofuji T, Hamachi T, Maeda K, Yokota M, Kido J, Nagata T, Kurihara H, Takashiba S, Sibutani T, Fukuda M, Noguchi T, Yamazaki K, Yoshie H, Ioroi K, Arai $\mathrm{T}$, Nakagawa $\mathrm{T}$, Ito $\mathrm{K}$, Oda $\mathrm{S}$, Izumi $\mathrm{Y}$, Ogata $\mathrm{Y}$, Yamada S, Shimauchi H, Kunimatsu K, Kawanami M, Fujii T, Furuichi Y, Furuuchi T, Sasano T, Imai E, Omae M, Yamada S, Watanuki M, Murakami S (2011) FGF-2 stimulates periodontal regeneration: results of a multi-center randomized clinical trial. J Dent Res 90(1):35-40. https:// doi.org/10.1177/0022034510384616

67. Emerton KB, Drapeau SJ, Prasad H, Rohrer M, Roffe P, Hopper K, Schoolfield J, Jones A, Cochran DL (2011) Regeneration of periodontal tissues in non-human primates with rhGDF-5 and betatricalcium phosphate. J Dent Res 90(12):1416-1421. https://doi. org $/ 10.1177 / 0022034511423665$

68. Bowen-Pope DF, Malpass TW, Foster DM, Ross R (1984) Plateletderived growth factor in vivo: levels, activity, and rate of clearance. Blood 64(2):458-469

69. Anusaksathien O, Giannobile WV (2002) Growth factor delivery to re-engineer periodontal tissues. Curr Pharm Biotechnol 3(2):129 139. https://doi.org/10.2174/1389201023378391

70. Carreira AC, Lojudice FH, Halcsik E, Navarro RD, Sogayar MC, Granjeiro JM (2014) Bone morphogenetic proteins: facts, challenges, and future perspectives. J Dent Res 93(4):335-345. https://doi.org/10.1177/0022034513518561

71. Rocque BG, Kelly MP, Miller JH, Li Y, Anderson PA (2014) Bone morphogenetic protein-associated complications in pediatric spinal fusion in the early postoperative period: an analysis of 4658 patients and review of the literature. J Neurosurg Pediatr 14(6):635-643. https://doi.org/10.3171/2014.8.Peds13665

Publisher's note Springer Nature remains neutral with regard to jurisdictional claims in published maps and institutional affiliations. 